\title{
Penerapan Metode Guide Inquiry untuk Meningkatkan Prestasi Belajar Matematika pada Siswa Kelas IV SD Negeri 2 Sukowiyono Tulungagung
}

\author{
Rince Sri Wahyuningsih ${ }^{1}$ \\ ${ }^{1}$ SD Negeri 2 Sukowiyono Tulungagung \\ Email: ${ }^{1}$ rincesri@gmail.com
}

\begin{tabular}{l}
\hline Tersedia Online di \\
\hline http://www.jurnal.unublitar.ac.id/ \\
index.php/briliant \\
\hline \\
\hline Sejarah Artikel \\
\hline Diterima pada 6 April 2018 \\
Disetuji pada 9 April 2018 \\
Dipublikasikan pada 13 Mei 2018 \\
Hal. 155-164 \\
\hline
\end{tabular}

Kata Kunci:

prestasi belajar, data dalam

bentuk tabel, guide inquiry

\section{DOI:}

http://dx.doi.org/10.28926/briliant .$v 3 \mathrm{i} 2.170$

\begin{abstract}
Abstrak: Berdasarkan hasil observasi yang dilakukan di Kelas VI pada waktu pembelajaran Matematika diperoleh hasil bahwa Prestasi belajar siswa kurang memuaskan. Untuk itu agar dapat meningkatkan Prestasi belajar siswa dalam menyelesaikan soal tentang Data dalam bentuk tabel serta untuk tercapainya tujuan pembelajaran perlu diadakan perbaikan pembelajaran dengan menerapkan Metode Guide Inquiry. Hasil penelitian menunjukkan bahwa penerapan Metode Guide Inquiry untuk meningkatkan Prestasi belajar siswa pada materi Data dalam bentuk tabel mempunyai kriteria keberhasilan baik. Hal ini dibuktikan dengan adanya peningkatan Prestasi belajar siswa berdasarkan nilai post test per siklus dengan nilai di atas KKM yaitu persentase pada siklus I 63,6\% dan pada siklus II 90,9\%..
\end{abstract}

Matematika merupakan ilmu yang menjadi dasar dari ilmu-ilmu yang lain. Bagi sebagian siswa matematika menjadi mata pelajaran yang dianggap sulit. Pada dasarnya matematika mengajak siswa agar dapat berpikir secara logika dan berpikir matematis, sedangkan matematika itu sendiri bersifat abstrak. Sehingga siswa mengalami kesulitan untuk memahaminya. Pembelajaran matematika harus melibatkan motivasi yang merupakan daya pendorong dan keinginan siswa agar siswa dapat berperan aktif, kreatif, efektif, dan menyenangkan selama proses pembelajaran berlangsung.

Suprijono (2012: 163) mengatakan bahwa "motivasi belajar adalah dorongan internal dan eksternal pada peserta didik yang sedang belajar untuk mengadakan perubahan perilaku".Motivasi belajar siswa dapat membawakan siswa ke arah tujuan belajar melalui beberapa faktor seperti respon-respon dari kebutuhan akan belajar dan akan muncul dari dalam diri siswa tersebut yang cenderung berwujud suasana emosi. Sardiman (2012: 83) mengemukakan bahwa indikator motivasi yang ada pada diri seseorang yaitu tekun menghadapi tugas, ulet menghadapi kesulitan, menunjukkan minat terhadap bermacam-macam masalah, dapat mempertahankan pendapatnya kalau sudah yakin akan sesuatu, dan kemandirian dalam tugas.

Djamarah (2012: 23) berpendapat bahwa "prestasi belajar adalah hasil yang diperoleh berupa kesan-kesan yang mengakibatkan perubahan dalam diri individu sebagai hasil dari aktivitas dalam belajar. Prestasi belajar merupakan hasil yang mengakibatkan perubahan pada individu sebagai hasil dari belajar. 
Hasil tersebut didapat siswa ketika selesai mengerjakan tugas dan kegiatan pembelajaran.Pencapaian prestasi belajar mencakup aspek kognitif, afektif atau psikomotor.Prestasi belajar yang didapatkan sesuai dengan aspek-aspek yang diamati untuk mendapatkan penilaian proses belajar yang menyeluruh.

Ruseffendi (1989, h. 23) menyatakan bahwa matematika itu terorganisasikan dari unsur-unsur yang tidak didefinisikan, definisi-definisi, aksioma-aksioma dan dalil-dalil, dimana dalil-dalil setelah dibuktikan kebenarannya berlaku secara umum.

Johnson dan Rising (1972) menyatakan bahwa matematika adalah pola berfikir, pola mengorganisasikan pembuktian yang logic; matematika adalah bahasa yang menggunakan istilah yang didefinisikan dengan cermat, jelas dan akurat representasinya dengan simbol dan padat, lebih berupa bahasa simbol mengenai arti daripada bunyi; matematika adalah pengetahuan struktur yang terorganisasi, sifat-sifat atau teori-teori dibuat secara deduktif berdasarkan kepada unsur yang tidak didefinsikan, aksioma, sifat atau teori yang telah dibuktikan kebenarannya.

Matematika sebagai ilmu dasar memegang peranan yang sangat penting dalam pengembangan sains dan teknologi, karena matematika merupakan sarana berpikir untuk menumbuhkan dan mengembangkan daya nalar, cara berpikir logis, sistematis dan kritis. Peranan matematika ini tidak hanya terasa dalam bidang matematika saja tetapi aplikasinya juga pada bidang- bidang lain. Keberhasilan pembelajaran Matematika tersebut tergantung pada siswa dalam proses belajar mengajar, sedangkan keberhasilan siswa tidak hanya tergantung pada sarana dan prasarana pendidikan, serta kurikulumnya. Akan tetapi, Guru dalam proses pembelajaran juga dapat mempengaruhi peningkatan prestasi belajar Matematika siswa, salah satunya dengan penggunaan metode pembelajaran yang tepat oleh Guru sesuai dengan materi yang disampaikan.

Menurut Syaiful Bahri Djamarah (2002: 12) proses belajar mengajar adalah suatu proses yang dilakukan secara sadar dan bertujuan. Tujuan ini yang menjadi arah ke mana proses belajar mengajar tersebut akan di bawa. Proses belajar mengajar akan berhasil jika mampu memberikan perubahan dalam pengetahuan, pemahaman, keterampilan, dan nilai sikap dalam diri siswa. Dalam proses pembelajaran di kelas sering timbul masalah yang pada umumnya dialami oleh siswa. Masalah yang dihadapi siswa bersifat unik berbeda satu sama lain. Misalnya masalah dan kesulitan ataupun rendahnya prestasi belajar yang dialami siswa pada mata pelajaran Matematika bisa terjadi karena berbagai faktor diantaranya. Keterbatasan kemampuan, keadaan, minat dan motivasi diri siswa itu sendiri. Situasi belajar di sekolah atau kelas dan kurangnya sarana dan prasarana. Materi pelajaran yang kurang relevan dengan kebutuhan siswa. Metode mengajar yang kurang bisa dipahami siswa bahkan kurangnya alat peraga dan alat bantu mengajar.

Apalagi mata pelajaran Matematika menuntut kemampuan Guru untuk bisa membuat siswa mengerti dan memahami tentang materi yang diajarkan dengan tidak hanya membaca buku dan teori saja melainkan harus disertai alat peraga, contoh, praktek, latihan soal, seperti soal bercerita dan sebagainya, agar siswa memiliki pengetahuan, keterampilan dan bahkan sikap ilmiah yang berujung pada pemerolehan prestasi belajar yang maksimal. 
Berdasarkan hasil pengamatan dalam proses belajar mengajar dikelas, keadaan sekolah, dan melalui peninjauan bidang akademik dan non akademik, diperoleh hasil bahwa keadaan SD Negeri 2 Sukowiyono Kecamatan Karangrejo khususnya siswa Kelas VI tahun ajaran 2017/2018 dalam pelajaran Matematika belum menunjukkan prestasi belajar sesuai dengan KKM yang ditetapkan terutama pada pengerjaan penyajian data dalam bentuk tabel. Padahal, ditinjau dari keadaan fisik sekolah, yaitu ruang Kelas VI sudah baik dan sesuai sebagai tempat berlangsungnya proses belajar mengajar. Pengamatan pada proses pembelajaran oleh peneliti dapat disimpulkan bahwa pelaksanaan proses belajar mengajar lah yang belum membuat siswa aktif belajar, sehingga kemampuan siswa belum tergali dengan maksimal.

Menurut Nana Sudjana (1989:28) belajar adalah proses yang diarahkan kepada tujuan, proses berbuat melalui berbagai pengalaman, melihat, mengamati dan memahami sesuatu. Oemar Hamalik (1999:37) berpendapat belajar adalah suatu proses perubahan tingkah laku siswa melalui interaksi dengan lingkungan. Pada ulangan harian Matematika dengan penyajian data dalam bentuk tabel, di dapat rata-rata nilai sebesar 63,5 dari 33 siswa, padahal Kriteria Ketuntasan Minimalnya (KKM) telah ditentukan nilai sebesar 70. Dan hanya 11 siswa yang mendapat nilai di atas 70 . Hal ini berarti, hanya 33,3\% dari siswa yang telah mencapai ketuntasan belajar, dan yang lainnya memiliki prestasi belajar yang rendah.

Berdasarkan hal tersebut, peneliti meminta bantuan kepada teman sejawat untuk meneliti kekurangan dari pembelajaran yang telah dilaksanakan. Dari hasil diskusi dengan teman sejawat ditemukan masalah-masalah dalam proses pembelajaran Matematika yang menyebabkan menurunkan prestasi belajar adalah sebagai berikut: 1) Materi kurang dapat dikuasi siswa secara optimal. 2) Siswa belum dapat menyelesaikan soal penyajian data dalam bentuk tabel. 3) Melihat hasil ulangan harian siswa diatas, bisa dilihat jika penggunaan metode pembelajaran dalam pembelajaran Matematika pada siswa Kelas VI belum sesuai dan membuat siswa terlihat tidak antusias untuk belajar. 4) Pembelajaran dengan metode konvensional yaitu dengan menjelaskan materi dan siswa hanya melakukan perintah mengerjakan soal tanpa penanaman konsep pembelajaran yang kuat ternyata tidak efektif dalam proses peningkatan prestasi belajar siswa.

Setelah melihat hasil analisa di atas dan tukar pendapat dengan teman sejawat, maka untuk memperoleh prestasi belajar yang optimal, tidak hanya memerlukan suatu latihan yang terus menerus, tetapi terlebih dahulu siswa harus mengetahui inti dari materi yang dipelajarinya. Berdasarkan konsep yang mereka temukan sendiri di dalam proses pembelajaran, tentu siswa akan lebih bersemangat, dan aktif belajar serta berusaha mencari penyelesaian masalah yang diberikan oleh Gurunya dengan menggunakan kemampuannya sendiri.

Adanya semangat atau motivasi siswa dalam belajar dan konsep yang tertanam dengan baik, diharapkan siswa mampu menyelesaikan setiap tugas yang diberikan dengan prosedur yang benar, sehingga prestasi belajar yang diperoleh menjadi lebih baik dari semula serta terjadi peningkatan prestasi belajar siswa.

Oleh karena itu, demi memperbaiki berbagai masalah yang ada, peneliti memerlukan suatu solusi untuk mengatasi hambatan-hambatan yang terjadi. Akhirnya diputuskan dengan menggunakan Metode Guide inquiry dalam pembelajaran Matematika ini. Metode Guide inquiry adalah metode pembelajaran 
yang menempatkan siswa bertanggungjawab secara penuh terhadap proses belajarnya, dan Guru hanya memberikan bimbingan terbatas pada pemilihan topik dan pengembangan pertanyaan. inquiry terbimbing (guided inquiry), di mana siswa diberikan kesempatan untuk bekerja merumuskan prosedur, menganalisis hasil dan mengambil kesimpulan secara mandiri, sedangkan dalam hal menentukan topik, pertanyaan dan bahan penunjang, Guru hanya berperan sebagai fasilitator.

Tujuan dari penggunaan metode guide inquiry dalam pembelajaran adalah mengembangkan kemampuan berpikir secara sistematis, logis dan kritis atau mngembangkan kemampuan intelektual sebagai bagian dari proses mental. Dengan demkian, dalam metode guide inquiry siswa tidak hanya dituntut agar menguasai materi pelajaran, akan tetapi bagaimana mereka dapat menggunakan kemampuan yang dimilikinya secara optimal. Metode guide inquiry dalam pembelajaran adalah mengembangkan kemampuan berpikir secara sistematis, logis dan kritis atau mngembangkan kemampuan intelektual sebagai bagian dari proses mental. Dengan demkian, dalam metode guide inquiry siswa tidak hanya dituntut agar menguasai materi pelajaran, akan tetapi bagaimana mereka dapat menggunakan kemampuan yang dimilikinya secara optimal.

\section{METODE}

Dalam pelaksanaan Penelitian Perbaikan Pembelajaran ini subjek adalah seluruh siswa Kelas VI SD Negeri 2 Sukowiyono Kecamatan Karangrejo Tulungagung tahun pelajaran 2017/2018 sebanyak 33 siswa.

Lokasi yang digunakan tempat penelitian adalah ruang Kelas VI SD Negeri 2 Sukowiyono Kecamatan Karangrejo Tulungagung Tahun Pelajaran 2017/2018. Penelitian dilaksanakan pada semester 1, pada tanggal 7 September 2017 sampai dengan 14 September 2017.

Berdasarkan variable yang diteliti dan tujuan yang hendak dicapai, mata metode penelitian yang digunakan adalah dengan teknik korelasi. Dengan berbagai metode yang digunakan peneliti, peneliti berupaya untuk meningkatkan prestasi belajar Matematika. Hasil pengidentifikasian dan penetapan masalah, peneliti kemudian mengajukan suatu solusi yang berupa penerapan Metode Guide inquiry yang dapat dimanfaatkan Guru untuk digunakan sebagai metode pengajaran dalam pembelajaran Matematika Kelas VI SD Negeri 2 Sukowiyono Kecamatan Karangrejo Tulungagung. Penelitian ini dilakukan dengan dua siklus, dimana masing-masing siklus dikenai perlakuan yang sejenis dengan bobot yang beda. Dibuat dua siklus dimaksudkan untuk memperbaiki system pengajaran yang dilaksanakan.

Adapaun ragam instrument penelitian tindakan kelas yang telah dipersiapkan yaitu, Rencana Pelaksaaan Pembelajaran sebagai instrument rencana pelaksanaan tindakan. Lembar observasi Guru sebagai instrument utama pengumpul data proses dan lembar observasi siswa, wawancara, angket dan catatan lapangan sebagai instrument pendukung pengumpul data proses. Selain itu juga terdapat instrument pengumpul data hasil, yang dapat dikumpulkan dari prestasi belajar berdasarkan soal-soal yang diberikan, serta ketrampilan siswa berdasarkan rubrik yang ada.

Teknik analisis yang digunakan yaitu deskriptif persentase. Data hasil penelitian yang dianalisis meliputi rata-rata kelas, ketuntasan belajar individu dan 
ketuntasan belajar secara klasikal. Selanjutnya hasil analisis data diperoleh baik secara kualitatif (dengan kata-kata) dan kuantitatif (dengan grafik). Hasil ini diinterprestasikan dan disimpulkan untuk menjawab permasalahan yang ada.

Analisis data dari sumber-sumber informasi hasil penelitian di dapat dari: 1) Analisis Data Observasi, Data hasil observasi keterlaksanaan pembelajaran melalui Metode Guide inquiry dan observasi aktivitas siswa dianalisis secara deskriptif untuk memberikan gambaran pelaksanaan pembelajaran dengan menggunakan Metode Guide inquiry. 2) Analisis Data Wawancara, Hasil wawancara dengan siswa dianalisi secara deskriptif dengan lembar angket untuk mengetahui pendapat Guru dan siswa terhadap pembelajaran. 3) Analisis Data Tes, Berdasarkan hasil tes siswa, setiap soal diberi skor kemudian diperoleh nilai untuk setiap siswa..

\section{HASIL}

\section{Pra Tindakan}

Sebelum melaksanakan proses penelitian, peneliti mengumpulkan data dan informasi tentang subjek penelitian. Data-data yang dikumpulkan antara lain daftar nama siswa Kelas VI, daftar nilai ulangan harian Matematika dengan penyajian data dalam bentuk tabel, hasil wawancara dengan informan yaitu siswa Kelas VI SD Negeri 2 Sukowiyono Kecamatan Karangrejo Tulungagung.

Dari pengumpulan data, nilai ulangan harian tentang penyajian data dalam bentuk tabel, rata-rata nilai yang didapat hanya sebesar 63,5. Dari 33 siswa, hanya 11 siswa yang mendapat nilai di atas 70. Ini berarti hanya 33,3\% siswa yang telah mencapai ketuntasan belajar, karena Kriteria Ketuntasan Minimal (KKM) telah ditentukan sebesar 70. Tabel berikut adalah daftar frekuensi nilai ulangan harian Matematika penyajian data dalam bentuk tabel siswa Kelas VI SD Negeri 2 Sukowiyono Kecamatan Karangrejo Tulungagung, dengan nilai KKM sebesar 70:

Tabel 1 Daftar Nilai Ulangan Harian Kondisi Awal

\begin{tabular}{|c|c|c|}
\hline Nilai & Frekuensi & Prosentase \\
\hline $0-40$ & 0 & $0,0 \%$ \\
\hline $41-69$ & 22 & $66,7 \%$ \\
\hline $70-100$ & 11 & $33,3 \%$ \\
\hline Jumlah & 33 & $100 \%$ \\
\hline
\end{tabular}

Dari tabel diatas dapat kita lihat terdapat 0 siswa atau $0,0 \%$ yang mendapat nilai antara $0-40$, ada 22 siswa atau $66,7 \%$ yang mendapat nilai antara 41 - 69, dan ada 11 siswa atau 33,3\% yang mendapat nilai antara $70-100$. Dengan ketentuan nilai KKM 70, maka dapat disimpulkan jika pencapaian prestasi nilai 70 - 100 yang hanya 33,3\% merupakan prestasi yang rendah. Selain itu, dari proses wawancara diperoleh kesimpulan bahwa siswa kurang berminat dalam melaksanakan kegiatan pembelajaran, serta dalam pembelajaran Guru lebih sering menggunakan ceramah sehingga siswa merasa jenuh dan bosan, akibatnya minat siswa untuk belajar Matematika terutama pada penyajian data dalam bentuk tabel menjadi berkurang sehingga mempengaruhi hasil prestasinya.

Berdasarkan hasil data yang dikumpulkan, dapat dikemukakan dua hal pokok yang perlu diatasi, yaitu menumbuhkan minat siswa untuk belajar 
Matematika dan memahamkan penyajian data dalam bentuk tabel dengan cara mengaktifkan siswa dalam kegiatan belajar mengajar dan meningkatkan prestasi belajar siswa dengan menerapkan Metode Guide inquiry pada siklus 1 nanti dengan harapan prestasi belajar siswa dapat meningkat.

\section{Siklus 1}

Pelaksanaan pembelajaran, Guru masih menghadapi berbagai kendala, antara lain: 1) Masih ada kelompok yang bingung dalam mengikuti langkahlangkah yang tertera dalam lembar kegiatan. 2) Masih ada beberapa siswa yang belum aktif dalam pelaksanaan percobaan. 3) Ketika pelaksanaan diskusi, ada beberapa siswa yang tidak aktif menyampaikan pendapatnya. 3) Dalam menyimpulkan hasil percobaan, terdapat 3 (tiga) kelompok yang malu untuk presentasi, dan hanya terdapat 3 (tiga) siswa yang mengajukan pertanyaan.

Adapun prosentase hasil observasi dalam pelaksanaan percobaan pada siklus I dapat dilihat dari tabel 3 bawah ini. Perhitungan prosentase keberhasilan siklus I di bawah ini diskusikan juga dengan teman sejawat.

Tabel 2 Prosentase Hasil Observasi Siklus I

\begin{tabular}{|l|l|l|}
\hline No & Kegiatan Siswa & Prosentase \\
\hline 1 & Kelengkapan menyiapkan alat dan bahan percobaan & $40 \%$ \\
\hline 2 & Keruntutan langkah-langkah dalam pelaksanaan kegiatan percobaan & $55 \%$ \\
\hline 3 & Keaktifan siswa selama melaksanakan kegiatan percobaan & $60 \%$ \\
\hline 4 & Keaktifan siswa dalam mengutarakan pendapat saat berdiskusi & $60 \%$ \\
\hline 5 & Kesimpulan akhir sesuai percobaan & $54 \%$ \\
\hline
\end{tabular}

Hasil post test pada siklus pertama dapat menjadi perhitungan persentase peningkatan prestasi belajar siswa. Dengan acuan penilaian tetap berdasarkan nilai KKM yang telah ditetapkan yaitu paling sedikit siswa memperoleh nilai 70 . Adapun rekapitulasi hasil test siklus I adalah sebagai berikut

Tabel 3 Hasil Post Test Siklus Pertama

\begin{tabular}{|l|l|l|}
\hline No & Deskripsi & Nilai \\
\hline 1 & Jumlah Nilai & 2390 \\
\hline 2 & Rata-rata Hasil Post Test & 72,4 \\
\hline 3 & Jumlah siswa yang mendapat nilai diatas KKM (70) & 21 \\
\hline 4 & Presentase siswa yang mendapat nilai diatas KKM (70) & $63,6 \%$ \\
\hline 5 & Jumlah siswa yang mendapat nilai dibawah KKM (70 & 12 \\
\hline 6 & Presentase siswa yang mendapat nilai dibawah KKM (70) & $36,4 \%$ \\
\hline
\end{tabular}

Nilai rata-rata hasil post test, dapat dihitung dari : $\dot{X}=\frac{\sum x}{\sum N}$, Jadi $\dot{X}=$ $\frac{2390}{33}=72,4$. Nilai KKM $=70$. Jadi sudah ada peningkatan prestasi belajar, namun hanya sedikit. Rumus Ketuntasan Individu (prestasi belajar siswa) = ¿ siswa yang mendapat nilai $\geq 70$ Esiswa $\quad$ x 100\%. Jadi, Ketuntasan Individu (prestasi belajar siswa) $=\frac{21}{33} \times 100 \%=63,6 \%$ 
Masing kurang dari indicator pencapaian siklus I sebesar 85\% atau lebih. Maka dilanjutkan percobaan pembelajaran dengan Metode Guide inquiry pada siklus II.

Tabel berikut adalah daftar frekuensi nilai post test siklus I Matematika penyajian data dalam bentuk tabel dengan soal pengerjaan siswa Kelas VI SD Negeri 2 Sukowiyono Kecamatan Karangrejo Tulungagung setelah pembelajaran menggunakan Metode Guide inquiry, dengan nilai minimal KKM sebesar 70:

Tabel 4 Daftar Nilai Ulangan Harian Siklus I

\begin{tabular}{|l|l|l|}
\hline Nilai & Frekuensi & Prosentase \\
\hline $0-40$ & 0 & $0,0 \%$ \\
\hline $41-69$ & 12 & $36,4 \%$ \\
\hline $70-100$ & 21 & $63,6 \%$ \\
\hline Jumlah & 33 & $100 \%$ \\
\hline
\end{tabular}

Dari tabel diatas dapat kita lihat terdapat 12 siswa atau $36,4 \%$ yang mendapat nilai antara 41 - 69, dan 21 siswa atau 63,6\% yang mendapat nilai antara 70 - 100. Dengan ketentuan nilai KKM 70, dapat disimpulkan jika pencapaian prestasi nilai $70-100$, maka prestasi belajar siswa telah meningkat dari $33,3 \%$ menjadi $63,6 \%$. Namun karena belum mencapai target indicator pencapaian siklus I sebesar $85 \%$ atau lebih, maka akan dilanjutkan ke Siklus II.

\section{Siklus II}

Dalam pelaksanaan proses pembelajaran, Guru telah melaksanakan perbaikan dari siklus I, siswa sudah mengalami kemajuan dan pelaksanaan-pun telah berjalan baik. Namun Guru menemukan masalah baru dalam pelaksanaan siklus II, yaitu: 1) Suasana gaduh di kelas, karena beberapa siswa menjadi saling berteriak satu sama lain. Namun diantisipasi oleh peneliti dengan memerintahkan ketua kelompok untuk mengkondisikan anggotanya. 2) Masih terdapat 3-4 siswa yang malu dalam presentasi dan kurang aktif dalam diskusi kelompok.

Adapun prosentase hasil observasi dalam pelaksanaan percobaan pada siklus II dapat dilihat dari tabel bawah ini. Perhitungan prosentase keberhasilan siklus II di bawah ini diskusikan juga dengan teman sejawat.

\section{Tabel 5 Prosentase Hasil Observasi Siklus II}

\begin{tabular}{|l|l|l|}
\hline No & Kegiatan Siswa & Prosentase \\
\hline 1 & Kelengkapan menyiapkan alat dan bahan percobaan & $80 \%$ \\
\hline 2 & Keruntutan langkah-langkah dalam pelaksanaan kegiatan percobaan & $90 \%$ \\
\hline 3 & Keaktifan siswa selama melaksanakan kegiatan percobaan & $85 \%$ \\
\hline 4 & Keaktifan siswa dalam mengutarakan pendapat saat berdiskusi & $92 \%$ \\
\hline 5 & Kesimpulan akhir sesuai percobaan & $89 \%$ \\
\hline
\end{tabular}

Hasil post test pada siklus kedua dapat menjadi perhitungan persentase peningkatan prestasi belajar siswa. Dengan acuan penilaian tetap berdasarkan nilai KKM yang telah ditetapkan yaitu paling sedikit siswa memperoleh nilai 70 . Adapun rekapitulasi hasil test siklus II adalah sebagai berikut: 
Tabel 6 Hasil Post Test Siklus Kedua

\begin{tabular}{|l|l|l|}
\hline No & Deskripsi & Nilai \\
\hline 1 & Jumlah Nilai & 2800 \\
\hline 2 & Rata-rata Hasil Post Test & 84,8 \\
\hline 3 & Jumlah siswa yang mendapat nilai diatas KKM (70) & 30 \\
\hline 4 & Presentase siswa yang mendapat nilai diatas KKM (70) & $90,9 \%$ \\
\hline 5 & Jumlah siswa yang mendapat nilai dibawah KKM (70 & 3 \\
\hline 6 & Presentase siswa yang mendapat nilai dibawah KKM (70) & $9,1 \%$ \\
\hline
\end{tabular}

Nilai rata-rata hasil post test, dapat dihitung dari : $\dot{X}=\overline{\Sigma N}$, Jadi $\dot{X}=$ $\frac{2800}{33}=84,8$. Nilai KKM $=70$. Jadi sudah ada peningkatan prestasi belajar yang signifikan. Rumus Ketuntasan Individu (prestasi belajar siswa) = Esiswa yang mendapat nilai $\geq 70$

Esiswa
siswa) $=\frac{30}{33} \times 100 \%=90,9 \%$.

Telah mencapai indicator pencapaian siklus II sebesar $85 \%$ atau lebih. Maka tidak perlu dilanjutkan percobaan pembelajaran dengan Metode Guide inquiry pada siklus III.

Tabel berikut adalah daftar frekuensi nilai post test siklus II Matematika dengan penyajian data dalam bentuk tabel siswa Kelas VI SD Negeri 2 Sukowiyono Kecamatan Karangrejo Tulungagung setelah pembelajaran menggunakan Metode Guide inquiry siklus II, dengan nilai minimal KKM sebesar 70:

Tabel 7 Daftar Nilai Ulangan Harian Siklus II

\begin{tabular}{|l|l|l|}
\hline Nilai & Frekuensi & Prosentase \\
\hline $0-40$ & 0 & $0,0 \%$ \\
\hline $41-69$ & 3 & $9,1 \%$ \\
\hline $70-100$ & 30 & $90,9 \%$ \\
\hline Jumlah & 33 & $100 \%$ \\
\hline
\end{tabular}

Dari tabel diatas dapat kita lihat terdapat 3 siswa atau $9,1 \%$ yang mendapat nilai antara 41 - 69, dan 30 siswa atau 90,9\% yang mendapat nilai antara 70 - 100. Dengan ketentuan nilai KKM 70, dapat disimpulkan jika pencapaian prestasi nilai $70-100$, maka prestasi belajar siswa telah meningkat dari $63,6 \%$ menjadi 90,9\%. Dengan 90,9\% maka telah tercapai indicator pencapaian siklus II sebesar yang $85 \%$ atau lebih, maka tidak perlu dilanjutkan ke Siklus III.

\section{PEMBAHASAN}

Berdasarkan hasil pelaksanaan pada siklus I, II dapat dinyatakan bahwa terjadi peningkatan kualitas pembelajaran yang tampak dan perolehan hasil evaluasi dan keaktifan siswa.

Dari tabel 2 siklus I hasil observasi menunjukkan, prosentase keberhasilan kelengkapan menyiapkan alat dan bahan percobaan $40 \%$, prosentase keruntutan langkah-langkah yang ditempuh dalam pelaksanaan percobaan $55 \%$, prosentase keaktifan siswa dalam melaksanakan kegiatan percobaan $60 \%$, 
prosentase keaktifan siswa dalam mengutarakan pendapat saat berdiskusi 54\% dan prosentase hasil penarikan kesimpulan akhir sesuai percobaan $50 \%$.

Berdasarkan tabel 5 siklus II hasil observasi menunjukkan, prosentase keberhasilan metode kelengkapan menyiapkan alat dan bahan percobaan siswa yang disiapkan $80 \%$, prosentase keruntutan langkah-langkah yang ditempuh dalam pelaksanaan percobaan $90 \%$, prosentase keaktifan siswa dalam melaksanakan kegiatan percobaan $85 \%$, prosentase keaktifan siswa dalam mengutarakan pendapat saat berdiskusi $92 \%$ dan prosentase hasil penarikan kesimpulan akhir sesuai percobaan $89 \%$.

Dapat kita lihat adanya prosentase kenaikan nilai Matematika mulai dari kondisi awal pra tindakan, diketahui baru 11 siswa atau 33,3\% yang mengalami ketuntasan belajar dan mendapatkan nilai sesuai dengan KKM. Hasil evaluasi siklus I menunjukkan baru 21 siswa atau 63,6\% yang mengalami ketuntasan belajar dan mendapat nilai sama dengan atau di atas KKM yaitu 70 . Hal itu menunjukkan bahwa pelaksanaan siklus I belum mencapai keberhasilan, karena indicator pencapaian adalah sebesar $85 \%$ atau lebih. Siklus II menunjukkan ada 30 siswa atau 90,9\% dari 33 siswa yang mengalami ketuntasan belajar. Sehingga peneliti menyimpulkan bahwa pada siklus II ini peneliti telah mencapai keberhasilan dari penelitian tindakan kelas yang telah dilakukan.

Ketika peneliti melaksanakan siklus I, peneliti mengalami berbagai kendala antara lain Banyak siswa yang belum memahami konsep pembelajaran. Masih ada kelompok yang bingung dalam mengikuti langkah-langkah yang tertera dalam lembar kegiatan. Masih ada beberapa siswa yang belum aktif dalam pelaksanaan percobaan. Ketika pelaksanaan diskusi, ada beberapa siswa yang tidak aktif menyampaikan pendapatnya. Dalam menyimpulkan hasil percobaan, terdapat 3 (tiga) kelompok yang malu untuk presentasi, dan hanya terdapat 3 (tiga) siswa yang mengajukan pertanyaan.

Peneliti kemudian melaksanakan siklus II sebagai perbaikan siklus I, sebelum pelaksanaan siklus II ini peneliti mengganti rencana pembelajaran Metode Guide inquiry baru yaitu dengan mencari permasalahan yang terjadi di lingkungan sekitar kemudian membuat diagram batang dari permasalahan yang terjadi.. Dalam pelaksanaan percobaan, peneliti senantiasa memberi bimbingan untuk siswanya dalam melaksanakan langkah-langkah sesuai lembar kegiatan. Peneliti pun memberi bimbingan siswa saat berdiskusi untuk menarik kesimpulan. Dengan adanya motivasi guru berupa reward, siswa telah terlihat aktif dalam kegiatan pembelajaran dalam melaksanakan percobaan, presentasi di depan kelas dan berdiskusi menarik kesimpulan. Meskipun ada kendala yaitu suasana gaduh di kelas, karena beberapa siswa menjadi saling berteriak satu sama lain., namun dengan hasil prestasi belajar yang dicapai dapat disimpulkan bahwa penelitian tindakan kelas dari siklus II ini telah berhasil.

Berdasarkan hasil observasi dan pelaksanaan siklus I dan II juga dapat kita amati adanya perubahan kenaikan prosentase dalam menyiapkan alat dan bahan, keruntutan langkah-langkah siswa dalam melaksanakan percobaan, keaktifan siswa dalam melaksanakan kegiatan percobaan, keaktifan siswa ketika berdiskusi dan hasil akhir atau simpulan yang diperoleh dari hasil kegiatan diskusi. 


\section{KESIMPULAN}

Berdasarkan hasil penelitian tindakan kelas yang telah dilaksanakan dalam 2 siklus dengan menerapkan Metode Guide inquiry dalam pembelajaran Matematika pada siswa Kelas VI SD Negeri 2 Sukowiyono Kecamatan Karangrejo Tulungagung, dapat dibuat kesimpulan sebagai berikut: Penerapan Metode Guide inquiry dapat meningkatkan prestasi belajar Matematika siswa Kelas VI SD Negeri 2 Sukowiyono Kecamatan Karangrejo Tulungagung.

\section{SARAN}

Berdasarkan hasil penelitian, maka ada beberapa saran yang dapat dipergunakan sebagai bahan pertimbangan dan sebagai bahan uraian penutup penelitian tindakan kelas ini, antara lain: (1) Bagi Guru, Hendaknya mempersiapkan secara cermat perangkat pendukung pembelajaran dan fasilitas belajar yang diperlukan, karena sangat mempengaruhi efektivitas dan efisiensi pembelajaran yang pada akhirnya berpengaruh pada proses dan prestasi belajar Matematika siswa. (2) Bagi Siswa, Hendaknya ikut berperan aktif dalam proses pembelajaran, selalu mengerjakan tugas-tugas yang diberikan guru dan meningkatkan usaha belajar sehingga dapat memperoleh prestasi yang diharapkan. (3) Bagi Sekolah, Hendaknya mengupayakan pengadaan berbagai media pembelajaran Matematika untuk kelas rendah, baik bantuan maupun swadaya sekolah, sehingga lebih menunjang dalam penanaman konsep-konsep Matematika secara lebih nyata sekaligus meningkatkan aktivitas belajar siswa.

\section{DAFTAR RUJUKAN}

Dimiyati., \& Mudjiono. 2002. Belajar dan Pembelajaran. Jakarta: Rineka Cipta. Djamarah, Syaiful Bahri. 2002. Psikologi Belajar. Jakarta: PT. Rineka Cipta. Nana, S. 2009. Penilaian Hasil Proses Belajar Mengajar. Bandung: Remaja Rosdakarya. 